\title{
Performance of the Solo Papaya (Carica papaya L.) in Puerto Rico ${ }^{1}$
}

\author{
T. Singh-Dhaliwal, A. Pérez-López, and J. López-Garcia ${ }^{2}$
}

INTRODUCTION

The Solo variety of papaya (Carica papaya L.) probably originated in Barbados, West Indies, and from there it was introduced into Hawaii. Soon it became the common commercial papaya in Hawaii. There its fruits are used locally and are also exported to the continental United States. ${ }^{3}$

Efforts are being made at this Station to develop papaya varieties giving high yields of high-quality fruits, and also resistant to virus diseases which limit the commercial production of this fruit. For this purpose several hundred papaya introductions, including the Solo variety, were obtained from abroad and tested during the past 3 years. As the Solo papaya is very well-known, inquiries are often received as to its performance in Puerto Rico. The results of this study of experimental plantings of the Solo papaya at the Fortuna and Isabela Agricultural Experiment Substations are briefly presented in this paper.

\section{MATERIALS AND METHODS}

The seed of the Solo papaya, Line 8 and the common type, were obtained from Hawaii. The seedlings were raised in the greenhouse during November 1959. During January and February 1960 they were planted in the field in rows 10 feet apart and 6 feet from hill to hill within the row. There were up to four seedlings in each hill. When the seedlings produced flowers they were thinned to retain two in each hill.

The cultural treatments given to experimental papaya plantings were almost the same as those in use for commercial plantings. However, the planting at Fortuna was not sprayed for the control of diseases and insects, and at Isabela spraying with DDT was carried on only during the first 6 months.

The papaya trees were individually studied as to sex form, fruiting height,

1 This investigation was carried on under the Commonwealth Research Project 166, Papaya Breeding.

2 Plant Breeder, and Assistant Agronomists, respectively, Agricultural Experiment Station, University of Puerto Rico, Rio Piedras, P.R.

${ }^{8}$ Jones, W. W., Storey, W. B., Parris, G. K., and Holdaway, F. G., Papaya Production in the Hawaiian Islands, Hawaii Agr. Expt. Sta., Univ. Hawaii, Honolulu, Hawaii, Bul. 87, 1941.

4 Compendio de Recomendaciones para la Producción de Cosechas, Misc. Pub. 1 (rev.), 78-80, Agr. Expt. Sta., Univ. P.R., 1954. 
and number of normal and misshapen fruits. The data on weight, length, and girth of fruits were collected by measuring random samples of two fruits from each tree. The random fruit samples were also studied as to thickness, color, and taste of their flesh.

The spread of the virus diseases, bunchy top, and the south-coast mosaic, in the papaya plantings was carefully observed.

\section{RESULTS}

\section{SEX FORM OF TREES}

At Fortuna as well as at Isabela both papaya progenies, Line 8 and the common type, comprised hermaphrodite and female trees. No male tree

TABLE 1.-Results of study of progenies of the Solo papaya (Caxica papaya L.) for sex form of trees at Fortuna and Isabela Agricultural Experiment Substations, P.R., during May to August $1960^{1}$

\begin{tabular}{l|c|c|c|c|c}
\hline \multirow{2}{*}{ Location of planting } & Progeny & \multicolumn{4}{|c}{ Data on sex form of trees } \\
\cline { 2 - 6 } & $\begin{array}{l}\text { Hermaph- } \\
\text { rodite }\end{array}$ & Female & Malc & Others \\
\hline Fortuna & Line 8 & 20 & 9 & 0 & 53 \\
Isabela & do. & 15 & 4 & 0 & 21 \\
Fortuna & Common type & 21 & 6 & 0 & 16 \\
Isabela & do. & 12 & 7 & 0 & 9 \\
& & 68 & 26 & 0 & 99 \\
\hline
\end{tabular}

1 The seed of the papaya progenies were sown in November 1959.

2 These plants were thinned out before blooming, hence their sex form was not known.

appeared. The number of hermaphrodite trees was more than twice the number of female trees (table 1).

The above results indicate that the seed lots of both progenies, though open-pollinated, came from hermaphrodite trees which did not receive pollen from any male tree ${ }^{8}$.

\section{YIELD AND FRUIT CHARACTERS}

The data on yield and fruit characters were collected during September to October 1960 (table 2).

The average fruiting height of the papaya trees varied from 61.00 to 68.40 inches, with an overall average of 64.84 .

The average number of fruits per tree varied from 9.00 to 19.86 , with an overall average of 14.15. The female trees produced relatively fewer fruits.

The average number of misshapen fruits per tree varied from 0 to 7 , with 
TABle 2.-Data on fruiting of the Solo papaya (Carica papaya L.) at Fortuna and Isabela Agricultural Experiment Substations, P.R., during September and October $1960^{1}$

\begin{tabular}{|c|c|c|c|c|c|c|c|c|c|c|c|c|}
\hline \multirow[b]{2}{*}{$\begin{array}{l}\text { Location } \\
\text { of planting }\end{array}$} & \multirow[b]{2}{*}{ Progeny } & \multirow[b]{2}{*}{$\begin{array}{c}\text { Trees } \\
\text { studied }\end{array}$} & \multirow[b]{2}{*}{ Sex form of trees } & \multicolumn{7}{|c|}{ Average for each progeny } & \multirow[b]{2}{*}{ Color of fruit fesh } & \multirow[b]{2}{*}{ Taste of fruits } \\
\hline & & & & $\begin{array}{l}\text { Fruiting } \\
\text { height }\end{array}$ & $\begin{array}{l}\text { Fruits } \\
\text { per tree }\end{array}$ & $\begin{array}{l}\text { Mis- } \\
\text { shapen } \\
\text { per tree }\end{array}$ & $\begin{array}{l}\text { Weight } \\
\text { of fruit }\end{array}$ & $\begin{array}{l}\text { Lengt] } \\
\text { of fruit }\end{array}$ & $\begin{array}{l}\text { Girth } \\
\text { of fruit }\end{array}$ & $\begin{array}{c}\text { Thick- } \\
\text { ness of } \\
\text { fruit } \\
\text { fresh }\end{array}$ & & \\
\hline Fortuna & Line 8 & $\begin{array}{l}\text { Number } \\
20\end{array}$ & Hermaphrodite & $\begin{array}{l}\text { Inches } \\
67.40\end{array}$ & $\begin{array}{l}\text { Number } \\
16.85\end{array}$ & $\begin{array}{c}\text { Number } \\
5.50\end{array}$ & $\begin{array}{c}\text { Pounds } \\
0.88\end{array}$ & $\begin{array}{l}\text { Inches } \\
4.90\end{array}$ & $\begin{array}{r}\text { Inches } \\
9.78\end{array}$ & $\begin{array}{c}\text { Inches } \\
1.75\end{array}$ & Yellow & Very sweet \\
\hline Do. & do. & 9 & Female & 66.44 & 9.00 & - & 1.13 & 4.28 & 12.36 & 1.71 & do. & Do. \\
\hline Do. & Common type & 15 & Hermaphrodite & 68.40 & 19.86 & 7.00 & .96 & 5.25 & 10.12 & 1.80 & $\begin{array}{l}\text { Yellow, some trees } \\
\text { reddish }\end{array}$ & Do. \\
\hline Do. & do. & 4 & Female & 64.00 & 16.75 & 1.75 & 1.35 & 4.92 & 13.15 & 1.75 & Yellow & Do. \\
\hline Isabela & Line 8 & 4 & Hermaphrodite & 66.00 & 14.50 & 3.25 & .70 & 7.10 & 8.40 & .62 & do. & Average sweetness \\
\hline Do. & Common type & 5 & do. & 61.00 & 11.00 & 2.20 & .67 & 5.55 & 9.50 & .71 & do. & Do. \\
\hline Do. & do. & 2 & Female & 61.50 & 12.50 & 一 & .80 & 5.00 & 12.00 & .60 & do. & Do. \\
\hline \multicolumn{3}{|c|}{$\begin{array}{l}\text { Average of } 2 \text { progenies at both } \\
\text { locations }\end{array}$} & Hermaphrodite & 65.70 & 15.55 & 4.48 & 0.80 & 5.70 & 9.45 & 1.22 & & \\
\hline \multicolumn{3}{|c|}{$\begin{array}{l}\text { Average of } 2 \text { progenies at both } \\
\text { locations }\end{array}$} & Female & 63.98 & 12.75 & 0.58 & 1.09 & 4.73 & 12.50 & 1.32 & & \\
\hline \multicolumn{3}{|c|}{ Grand average } & & 64.84 & 14.15 & 2.53 & 0.94 & 5.21 & 10.97 & 1.27 & & \\
\hline
\end{tabular}

1 The papaya trees were about 1 year old when studied. 
an overall average of 2.53 . The female trees produced relatively fewer misshapen fruits.

The average weight of fruits varied from 0.67 to 1.35 pounds, with an overall average of 0.94 . The fruits from female trees were relatively heavier.

The average length of fruits varied from 4.28 to 7.10 inches, with an overall average of $; .21$. The fruits from hermaphrodite trees were relatively longer.

The average girth of fruit varied from 8.40 to 13.15 inches, with an overall average of 10.97 . The fruits from female trees were relatively thicker.

The average thickness of fruit flesh varied from 0.60 to 1.80 inches with an overall average of 1.27 .

The color of fruit flesh was yellow, except in some trees from the commontype progeny at Fortuna which produced fruits with slightly reddish flesh. Both progenies were from open-pollinated seed, hence variability for color of fruit flesh may have been owing to spontaneous hybridation involving some papaya types with red fruit flesh.

The fruits produced at Fortuna were sweeter and better flavored than those produced at Isabela. This may be because of differences in soils and climate between these locations, and also the fact that the papaya trees at: Isabela were relatively more heavily fertilized. The fruits infected with virus cliseases had very little or no sweetness, and had off-flavor even when fully ripe.

\section{UTILIZATION OF FRUITS}

All persons who ate the virus-free ripe fruits relished their taste and flavor very much. But the fresh virus-infected ripe fruits were unacceptable. Fruits infected with the south-coast mosaic had numerous dark spots on their skins and thus appeared to be quite unattractive.

In Puerto Rico the buyers are accustomed to purchase large-sized fruits; therefore, they were not eager to buy small-sized fruits of the Solo variety, in spite of the fact that they were sold by weight and not by number.

\section{DISEASES AND INSECT PESTS}

At Fortuna during the first 6 months the papaya planting seemed to be free of virus diseases. Later on the spread of diseases was rapid. By the end of 1 year all the papaya trees were severely infected with the south-coast mosaic and some of them with bunchy top also. The trees became highly chlorotic and stopped growing. Therefore, they were removed from the field.

At Isahela during the first 6 months the papaya planting seemed to be free of bunchy top; later its spread was very rapid. By the end of 1 year all the trees were severely infected with bunchy top. However, none of 
them showed symptoms of the south-coast mosaic. They became highly chlorotic and stopped growing. Therefore, they were removed from the field.

At Fortuna some papaya trees died from root rot and, at Isabela there were dark spots on old leaves of some trees, possibly caused by some fungal disease. In general, however, these latter diseases were not serious enough to warrant detailed investigation. Likewise, there was no direct serious damage from insect pests ${ }^{5}$.

\section{POSSIBILITIES OF COMMERCIAL PRODUCTION}

The fully-ripe fruits of the Solo papaya are sweet and have good flavor. Thus, they are very desirable for use fresh. The prejudice against their small size may disappear when consumers get better acquainted with their good characteristics.

One drawback of the Solo papaya is that it does not produce as heavy a crop as some of the large-sized papaya types commonly grown in Puerto Rico. Another drawback is its extreme susceptibility to both the southcoast mosaic and bunchy top diseases. The control of these diseases, especially the former on the south coast, would appear to be difficult and costly.

On the basis of the present study it is not possible to recommend the establishment of large commercial plantings of the Solo papaya. However, interested fruit growers may establish small plantings to find out whether, by proper care, they can obtain fair-sized crops, and also whether there is a possibility of their sale, both locally and in the continental United States markets.

\section{SUMMARY}

The Solo papaya (Carica papaya L.), which is the common commercial papaya in Hawaii, was introduced into Puerto Rico. Its performance was studied at the Fortuna and Isabela Agricultural Experiment Substations of this Station.

The plantings comprised hermaphrodite and female trees. No tree of male form appeared.

The trees started bearing fruits at a height of little more than 5 feet. When about a year old the average number of fruits per tree was 14.15, of which 2.53 were misshapen. The average weight of the fruits was 0.94 pounds; length, 5.21 inches; girth, 10.97 inches; and thickness of flesh, 1.27 inches. The color of the flesh of most of the fruits was yellow and they had good taste and flavor.

The female trees were less productive than the hermaphrodite trees, but

- The bunchy top of papaya, a virus disease, is transmitted by the leafhopper, Empoasca papayae Oman; mosaic of papaya is transmitted by the green citrus aphid, A phis spiraecola Patch. 
had fewer misshapen fruits. The fruits from female trees were relatively heavier and roundish in shape.

By the end of 1 year in the field all the trees became severely infected with virus diseases, the south-coast mosaic and bunchy top, and stopped growing and bearing.

On the basis of the present study the Solo papaya is not recommended for large-scale commercial production in Puerto Rico. However, interested fruit growers may test its performance on their farms by establishing small plantings.

\section{RESUMEN}

Se introdujo la variedad Solo de papaya (Carica papaya L.) que es la que se cultiva comercialmente en Hawaii. El comportamiento de esta variedad en Puerto Rico se estudió en las subestaciones experimentales agrícolas en Fortuna e Isabela.

Las siembras comprendieron plantas hermafroditas $\mathrm{y}$ hembras. No apareció planta alguna con floración masculina.

Los arbustos comenzaron a producir frutas cuando alcanzaron una altura de poco más de 5 pies. Cuando tuvieron un año de sembrados el número de frutas por arbusto alcanzó un promedio de 14.15, de las cuales 2.53 frutas eran de tamaño y forma irregular. El peso promedio de las frutas fué de 0.94 libras; con longitud de 5.21 pulgadas; grosor de 10.97 pulgadas y espesor de la pulpa de 1.27 pulgadas. El color de la pulpa de la mayoría de las frutas fué amarillo. El sabor resultó aceptable.

Al comparar la producción de los arbustos hembras con los hermafroditas se observó que los primeros produjeron menos frutas que los segundos, pero tuvieron menos frutas de tamaño y forma irregular. Las frutas de estos arbustos hembras fueron relativamente más pesadas y de forma más redonda.

Al terminar su primer año en el campo todos los arbustos fueron severamente atacados por las enfermedades virosas llamadas el mosaico de la costa sur y el mal de la papaya (bunchy top). Todos los arbustos enfermos dejaron de crecer y producir.

De lo que se desprende del presente estudio, no es juicioso recomendar la variedad Solo para siembras en escala comercial en Puerto Rico. Sin embargo, no estaría de más que los agricultores interesados hicieran pequeñas siembras para probar su comportamiento bajo las condiciones locales de sus fincas. 